\title{
MOBILE PROTONS IN SUPERPROTONIC CONDUCTORS OF PHOSPHATE GLASSES AND pH-ELECTRODE GLASSES
}

\author{
YOSHIHIRO ABE \\ College of Engineering, Chubu University, \\ Matsumoto-cho, Kasugai-shi, Aichi, 487-8501 Japan
}

\begin{abstract}
In oxide glasses, strongly hydrogen-bonded protons which give IR absorption band at around $2900 \mathrm{~cm}^{-1}$ are very mobile, while hydrogen-bonding free protons which give its band at around $3600 \mathrm{~cm}^{-1}$ are immobile or much less mobile. The mobilities of protons increase with the strength of the hydrogen bonding. The superprotonic conductors of oxide glasses are developed for the phosphate glasses containing a large amount of mobile protons and molecular water. The theories of potential development of $\mathrm{pH}$-glass electrodes which are long pending problem are discussed in terms of the mobile protons of the glasses. We assert that the presence of the mobile protons is indispensable for its $\mathrm{pH}$-response.
\end{abstract}

\section{INTRODUCTION}

Recently, mobile protons in glasses and high proton-conducting glasses have much attraction from a view point of scientific and/or technological point. A series of studies on protonic conduction in oxide glasses have been reported by us. ${ }^{1-27}$ We pointed out that high proton-conducting membranes of inorganic glasses will be demanded for solid electrolytes of hydrogen-oxygen fuel cells. ${ }^{1,2}$ The presence of an amount of high mobility protons is a requisite condition for developing fast protonconducting glasses or superprotonic conductors of glasses; we assert that it also plays an essential role in the potential development of $\mathrm{pH}$-electrode glasses. ${ }^{4 \mathrm{~L}-49}$ High mobility protons in glasses give important effects on their electrical properties and applications

Unfortunately, however, it has been long believed that protons in glasses are substantially immobile, ${ }^{29}$ and they have no essential role on the (d.c) electrical condu ction of the glasses. On the other hand, as we have reported since $1982,{ }^{1,2}$ strongly hydrogen-bonded protons in glasses have been found to be very mobile, although protons free from hydrogen-bonding are substantially immobile. The mobility of the hydrogen-bonded protons in $\mathrm{pH}$-glasses has been evaluated to be much higher than that 
of alkali-ions. ${ }^{49}$

The role of protons in protonic and superprotonic conductors of phosphate glasses, and that of $\mathrm{pH}$ electrode glasses are reviewed in the present paper.

\section{PROTONIC CONDUCTION} INGLASSES

These were presented at 17 th $\mathrm{ICG}^{12}$ and 3 rd ISIPM ${ }^{28}$, and summarized as follows.

\section{(a) Protonic Conduction in Glasses Without Molecular Water}

Normally melt-quenched glasses contain substantially no molecular water, but contain hydroxyl groups $(-\mathrm{OH})$ as an impurity in which hydrogen-bonding free protons

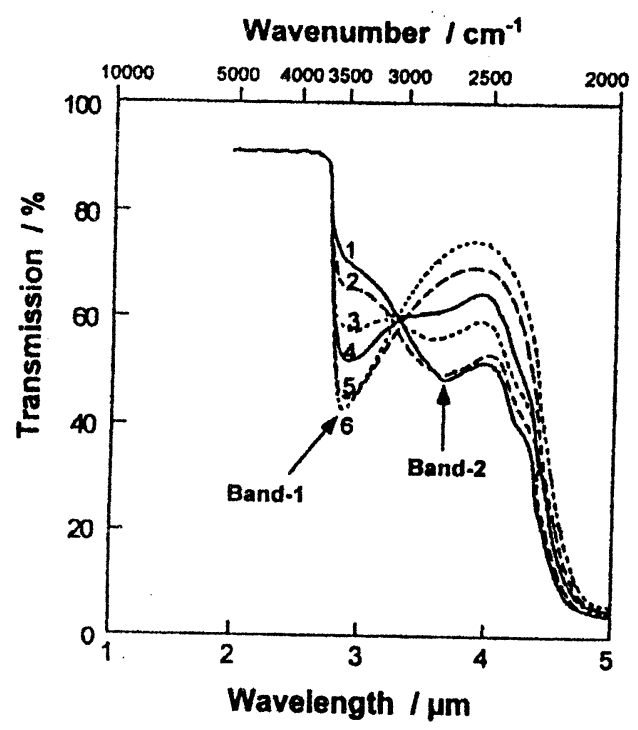

FIGURE 1. Typical example of IR absorption spectra of $20 \mathrm{Na}_{2} \mathrm{O}-\mathrm{xAl}_{2} \mathrm{O}_{3}-(80-\mathrm{x}) \mathrm{SiO}_{2}$ glasses (after Scholze ${ }^{30}$ ).
(1) $\mathrm{x}=0$,
(5) $x=15$,
(2) $x=5$, (3) $x=10$,
(6) $x=20$.
(4) $x=12$,

(immobile) and strongly hydrogen-bonded protons (mobile) are present.

Fig.1 shows IR absorption spectra for $\mathrm{Na}_{2} \mathrm{O}-\mathrm{Al}_{2} \mathrm{O}_{3}-\mathrm{SiO}_{2}$ glasses which is a typical example given by Scholze. ${ }^{30}$ It is interesting that the peak wavenumber of the absorption band due to hydroxyl groups depends strongly on the glass structure or composition. The band-1 shown in Fig. 1 is hydrogen-bonding free, and the band-2 is strongly hydrogen-bonded. The specimen- 6 gives only one band (band-1) as in silica glass, and no band-2. We found that protons of band-1 is "immobile" (less mobile) under an electrical d.c. field and those of band- 2 is "mobile".

Generally, alkaline earth phosphate glasses, $\mathrm{MO}-\mathrm{P}_{2} \mathrm{O}_{5}$, give strong absorption at around $2900 \mathrm{~cm}^{-1}$ (band-2); the peak absorption wavenumber $\left(\nu_{\mathrm{OH}}\right)$ shifts to lower one with increasing ionic radius of $\mathrm{M}$-ion.

Generally, alkaline earth phosphate glasses, MO- $\mathrm{P}_{2} \mathrm{O}_{5}$, give strong absorption at around $2900 \mathrm{~cm}^{-1}$ (band-2); the peak absorption wavenumber $\left(v_{\mathrm{OH}}\right)$ shifts to lower one with increasing ionic radius of $\mathrm{M}$-ion.

The results obtained so far are briefly summarized as follows.

(1) There exist two types of protons in oxide glasses, "immobile ( or less mobile) protons" and "mobile protons". The IR absorption bands due to O-H stretching appear at $\nu_{\text {OH }} \approx 3600 \mathrm{~cm}^{-1}$ ( band-1, free from hydrogen bonding ) and $\nu_{\text {OH } \approx}$ 
$2900 \mathrm{~cm}^{-1}$ ( band-2, strongly hydrogen-bonded ) which shift depending on glass structure and compositions. (It has been known that glasses containing non-bridging oxygens have band-2.)

(2). The protonic conductivities ( $\sigma, \mathrm{S} / \mathrm{cm}$ ) are not proportional to the concentration of protons, but are proportional to the square of the concentration of carrier protons $\left(\left[\mathrm{H}^{+}\right], \mathrm{mol} / \mathrm{l}\right)$.

$$
\sigma=\mathbf{A}_{\mathbf{H}}\left[\mathbf{H}^{+}\right]^{2}
$$

(3) The constant, $\mathbf{A}_{1 \mathrm{I}}$ (a mobility term) increases considerably with the wavenumber $\left(v_{\mathrm{oH}}\right)$; it increases approximately by one order with the shift of $100 \mathrm{~cm}^{-1}$ of $v_{\mathrm{on}}$.

$$
\log A_{11}=-0.00970 v_{\text {on }}+17.1
$$

Where, $\mathbf{A}_{\mathbf{H}}$ is a proportional factor in the equation (1), a measure of mobility, of plotting of conductivity at $417 \mathrm{~K}(150 \mathrm{C})$ vs square of concentration of mobile protons. Thus, it is surprising that the mobilities of the protons in $\mathrm{Ba}\left(\mathrm{PO}_{3}\right)_{2}$ glasses

$$
\begin{aligned}
& \left(\nu_{\text {of }} \approx 2800 \mathrm{~cm}^{-1}\right) \text { are } 10^{7} \sim 10^{8} \text { times higher than those of } \mathrm{SiO}_{2} \text { glasses }\left(\nu_{\mathrm{oH}}\right. \\
& \left.\approx 3650 \mathrm{~cm}^{-1}\right) .
\end{aligned}
$$

(4) It is very effective for the preparation of high proton-conducting glasses that the glasses contain phosphates.

(5). The experimental activation energies for the protonic conduction $\left(E_{1 H}\right)$ which are obtained from Arrhenius plots are expressed by the following equation.

$$
\begin{aligned}
& \mathbf{E}_{\mathrm{II}}=\mathbf{E}_{0}+\mathbf{E}_{1} \ldots \ldots \ldots \ldots \ldots \ldots \\
& \mathbf{E}_{0}=\mathbf{B}_{0}+\mathbf{B}_{1} v_{\text {oH }} \ldots \ldots \ldots \ldots \ldots \\
& \mathbf{E}_{1}=-\mathbf{B}_{2} \log \left[\mathbf{H}^{+}\right] \ldots \ldots \ldots \ldots
\end{aligned}
$$

( $\mathrm{B}_{0}, \mathrm{~B}_{1}$, and $\mathrm{B}_{2}$ are const.)

$E_{0}$ is the value for $\left[\mathrm{H}^{+}\right]=1 \mathrm{~mol} / 1$; this is considered to be related to breaking of

$\mathrm{O}-\mathrm{H}$ bond; $\mathrm{E}_{1}$ depends on the hopping distance or proton concentration )

(6) Both protonic conductivity and activation energy of a given glass can be evaluated (by applying the above experimental equations) from the IR absorption spectrum of a given glass plate, without the electrical measuring.

As an example of the estimation of activation energy in protonic conduction of a given glass, we have applied the above equations to $\mathrm{PbO}_{-} \mathrm{SiO}_{2}$ glasses. ${ }^{7}$ The nature of electrical charge carriers of the lead silicate glasses was a long pending question. Milnes $(1962)^{31}$, Cohen $(1973)^{32}$, Melling $(1979)^{33}$, Dutta.$(1988)^{34}$ et al. supported the view that the $\mathrm{Pb}^{2+}$ were assumed to be the charge carriers. On the other hand, Hugheses $(1968)^{35}$ suggested that the carriers are not $\mathrm{Pb}^{2+}$ but either $\mathrm{H}^{+}$ions or electrons. Topping $(1974)^{36}$ also suggested $\mathrm{H}^{+}$ions are quite likely to be the dominant charge carriers. By contrast with the different results so far obtained, we estimated the activation energies ( $\mathrm{E}$ ) using the above equations, in which $v_{\mathrm{OH}}$. of $\mathrm{PbO}-\mathrm{SiO}_{2}$ glasses 
was substituted, and concluded that the current carriers are the hydrogen-bonded (mobile) protons. ${ }^{7}$

\section{(b) Superprotonic Conduction in Glasses with Molecular Water}

We have pointed out that glasses containing no molecular water give no superprotonic conductivities such as $10^{-1}$ to $10^{-5} \mathrm{~S} / \mathrm{cm}$ at room temperature. ${ }^{12-a}$ The first superprotonic conductors of inorganic gel-glasses ${ }^{12-b}$ containing a large amount of molecular water and mobile protons were prepared by us for zirconium phosphate systems by a common sol-gel processing. ${ }^{12,13,15}$ The conductivities are shown in Fig. 2 . $^{15}$ The mobility of protons of $\mathrm{SiO}_{2}$ glasses (or $\mathrm{A}_{\mathrm{H}}$ ) is very low as estimated from equation (2), and then, phosphates were selected. The first developed superprotonic conductors of $\mathrm{ZrO}_{2}-\mathrm{P}_{2} \mathrm{O}_{5}$ gel-glasses have several weak points such as difficulty of glass formation and conductivity drop above $100 \mathrm{C}$, and since then, the system glasses in $\mathrm{ZrO}_{2}-\mathrm{P}_{2} \mathrm{O}_{5}-\mathrm{SiO}_{2}{ }^{20,21}$ and $\mathrm{P}_{2} \mathrm{O}_{5}-\mathrm{SiO}_{2}{ }^{26}$ have been tried. These silica-containing glasses are stable up to about $400 \mathrm{C}$, and give high conductivities. However, it is widely known that sol-gel derived glasses are hardly prepared into large bulky forms such as 5 $\mathrm{cm} \times 5 \mathrm{~cm}$ membranes owing to the crack formation during sol-gel preparation; this is a common weak point of the sol-gel processing.

Recently we are now trying to develop a new processing for producing larger specimens of superprotonic conductors of transparent oxide glasses ${ }^{37}$ which is not from sol-gel processing. The current carriers of the glasses are not $\mathrm{H}_{3} \mathrm{O}^{+}$but $\mathrm{H}^{+}$; the glasses contain no connective micro-pores such as those in sol-gel derived gel-glasses and in perfluorosulfonic polymers $\left(\right.$ Nafion $\left.^{R}\right)$; the absorption edges of these transparent and colorless glasses are around $230 \mathrm{~nm}$ in the ultraviolet region.

Concepts of some applications of the glasses to clean energy fields are shown in Fig. 3-5, where photocatalytic semiconductor of titania is used as an example. The photocatalytic splitting of water into hydrogen and oxygen using a semiconductor of $\mathrm{TiO}_{2}$ were first found by Honda \& Fujishima ${ }^{38}$, it operates with ultraviolet light.

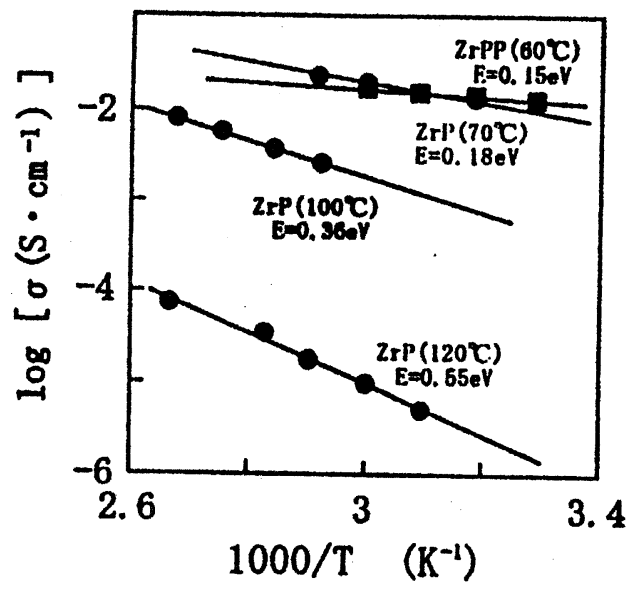

FIGURE 2. Arrhenius plots of protonic conductivities for sol-gel derived zirconium phosphate glaseses. (Atomic ratios $\mathrm{P} / \mathrm{Zr}$ for $\mathrm{ZrP}$ and $\mathrm{ZrPP}$ are 4 and 3, respectively.) 
Recently, the oxide photocatalysts which operate with visible light ${ }^{39.40}$ have been developed. The place where the function of the system of Fig. 4 and/or Fig. 5 is most effective will be outer space which is irradiated by very strong solar rays including ultraviolet light. In Fig.5, the $\mathrm{O}_{2}$ and $\mathrm{H}_{2}$ which are produced by photolysis are used for the $\mathrm{H}_{2}-\mathrm{O}_{2}$ fuel cell, from which electric energies are available to result in the formation of $\mathrm{H}_{2} \mathrm{O}$.
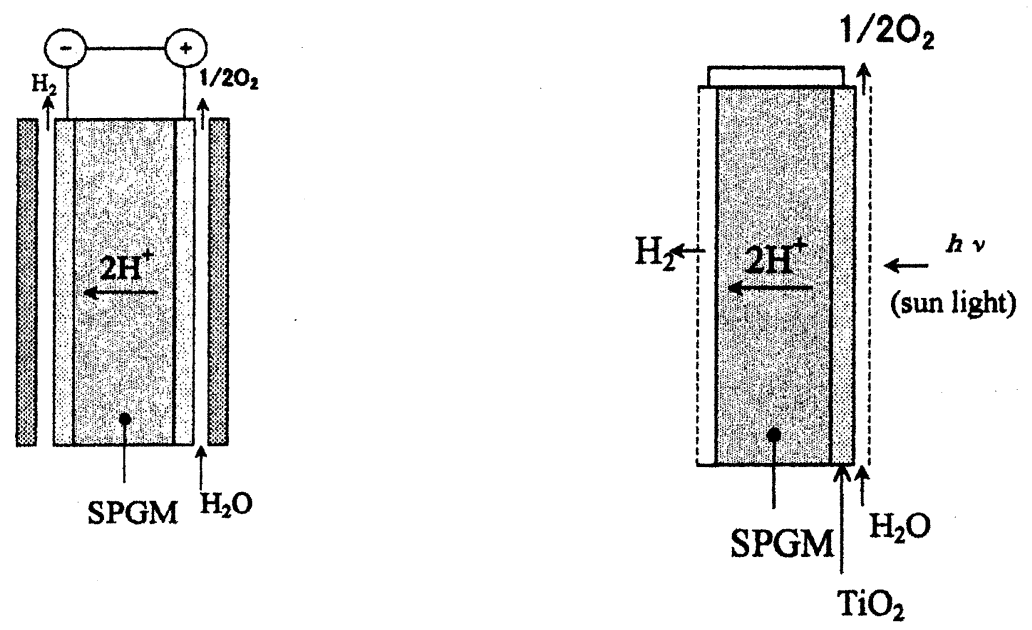

FIGURE 3. Electrolysis of water. (SPGM: superprotonic condutors of

FIGURE 4. Electrochemical photolysis glassy membranes)

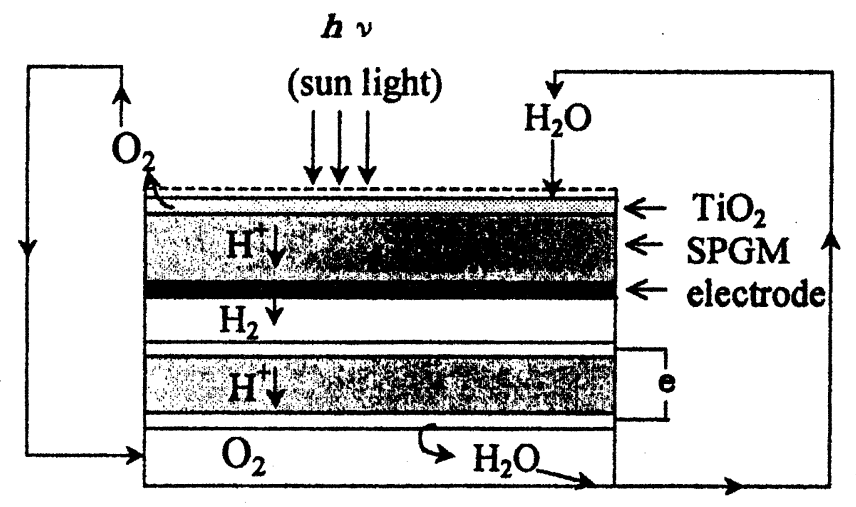

FIGURE 5. Concept of circulation type of the system. Combination of water photolysis \& its use to $\mathrm{H}_{2}-\mathrm{O}_{2}$ fuel cells. 
Summaries :

(1) Protonic conductivity increases considerably with the introduction of molecular water into glasses. The activation energy decreases in proportion to $\log \left[\mathrm{H}_{2} \mathrm{O}\right]$.

(2) Superprotonic conductors of glasses were developed by sol-gel processing for the systems of $\mathrm{ZrO}_{2}-\mathrm{P}_{2} \mathrm{O}_{5}, \mathrm{ZrO}_{2}-\mathrm{P}_{2} \mathrm{O}_{5}-\mathrm{SiO}_{2}$, and $\mathrm{P}_{2} \mathrm{O}_{5}-\mathrm{SiO}_{2}$, all of which contain a large amount of molecular water and mobile protons. Some of them are stable at around $400 \mathrm{C}$.

(3) Preparation of superprotonic conductors of oxide glasses via another new route is in progress.

These membranes have a potential use for the proton-conducting electrolytes such as for those of electrolysis and photolysis of water and $\mathrm{H}_{2}-\mathrm{O}_{2}$ fuel cells.

\section{ROLE OF PROTONS IN pH-ELECTRODE GLASSES}

We have reported a series of studies on the mechanisms of $\mathrm{pH}$-electrode glasses. ${ }^{41-49}$ The $\mathrm{pH}$-electrode glass membranes commercially obtained are regarded as a kind of hydrogen ion $\left(\mathrm{H}^{+}\right)$sensors. In spite of the lapse of about one century since the discovery of $\mathrm{pH}$-responsive glass electrodes, theories or mechanisms for the origin of the potential development of the glass electrodes seem to remain unsolved. Most theories presented so far for the potential development are mainly based on the assumption that hydrogen ions (protons) in the aqueous solution do not diffuse through the glass membrane. That is to say, all recent theories for $\mathrm{pH}$-glass electrodes are originated from the hypotheses accepting the immobility of protons in the glasses, and then they are complicated and seem to be somewhat mysterious.

Table 1 gives major theories (mechanisms) for the development of $\mathrm{pH}$-glass electrode potential. At the initial stage of the discovery after $\mathrm{Cremer}^{50}$, it has been supposed that glass membrane is permeable to $\mathrm{H}^{+}$ions. Dole ${ }^{51}$ assumed that $\mathrm{pH}$-glass electrodes are semi-permeable membranes only to hydrogen ions and derived the electrode potential equation based on diffusion potentials. However, in 1941-1962, Haugard $^{52}$, Schwabe ${ }^{53}$ and Hammond ${ }^{54}$ concluded "as a result of their experiments" that $\mathrm{H}^{+}$ions do not permeate through the glasses. Since then, theories excluding the $\mathrm{H}^{+}$diffusion have been widely proposed up to the present. Nevertheless, we like to assert that $\mathrm{H}^{+}$ions diffuse through the glass membranes during measurement of $\mathrm{pH}$.

In recent text books ${ }^{55}$ so far published, theories excluding the $\mathrm{H}^{+}$-diffusion are described. For example, in ref.(55-a) the following sentences appear:

"It was formerly believed that the potential of the glass electrode arose from the migration of $H^{*}$ through the glass. If $H^{*}$ could do this, and 
other ions could not, then a potential analogous to a liquid junction potential would develop across the membrane and a Nernstian response to It would bo expected. Ilowever, it has apparently been domonstrated that It does not in fact traverse the membrane, and other ideas. (which are unfortunately more difficult to explain) have been developed."

In contrast, we assert that hydrogen ions of glasses having non-bridging oxygens are mobile, that is, the strongly hydrogen-bonded protons of glasses are mobile, and they are responsible for the potential development of the glass electrode...

\section{Mobility of Hydrogen Ions in pH-Electrode Glasses}

The diffusion theories that hydrogen ions of solution diffuse into the glassmembrane have been disproved by the Hammond's experiment. ${ }^{54} \mathrm{He}$ concluded that hydrogen ions do not diffuse into the glass membrane and cations other than hydrogen ions carry the current across the membrane. Recently, however, we have pointed out that his conclusion is not correct ${ }^{41}$

It has been often believed that hydrogen ions (protons) in oxide glasses are hardly mobile ${ }^{29}$ or their mobilities in them are much lower than those of alkali ions. The mobility ratio of $\mathrm{H}^{+}$ion to $\mathrm{Li}^{+}$ion $\left(\boldsymbol{\mu}_{\mathrm{H}} / \boldsymbol{\mu}_{\mathrm{Li}}\right)$ in a commercial pH-responsive glass ("Liglass") has been reported by Baucke and Gach ${ }^{56}$ to be about 1/ 56. In contrast, according to our caluculation by using eq.(2), $\boldsymbol{\mu}_{\mathrm{H}}$ is evaluated to be much higher than $\boldsymbol{\mu}_{\mathrm{Li}}\left(\boldsymbol{\mu}_{\mathrm{H}} / \boldsymbol{\mu}_{\mathrm{Li}} \text { ratio } \fallingdotseq 10^{3}\right)^{49}$. In their experiment, the glass membrane was subjected to an electrical field of $6000 \mathrm{~V} \mathrm{~cm}^{-1}$ in a dilute sulfuric acid in such a way that the hydrogen ions in the solution were introduced into the specimen. It is apparent that, as shown in Fig.6, the introduced $\mathrm{H}^{+}$ions replaced by $\mathrm{Li}^{+}$ion result in the increase of $\mathrm{H}^{+}$concentration of the glass; these increased $\mathrm{H}^{+}$ions are not intrinsic hydrogen ions which are originally present in the glass, but extrinsic ones. The concentration of the intrinsic $\mathrm{H}_{(2)}^{+}$ions, which give IR band -2 in Fig. 1 and are mobile, should remain constant before and after the voltage is applied.

As seen in Fig.7, the pH-glass contains the highest concentration of mobile protons (band-2). On the assumption that hydrogen ions in solution diffuse into $\mathrm{pH}-$ glass membranes during measurement of $\mathrm{pH}$, it is proposed that the potential, $\mathrm{E}$, is expressed by eq. 6 , when $\mathrm{H}^{+}$- and alkali $\left(\mathrm{M}^{+}\right)$- ions are present in the solution. ${ }^{43,46,49}$

$$
\mathrm{E}=(\mathrm{RT} / \mathrm{F}) \ln \left(\boldsymbol{\mu}_{\mathrm{H}}{ }^{8} \mathrm{C}_{\mathrm{H}}{ }^{\mathrm{T}}+\boldsymbol{\mu}_{\mathrm{H}}{ }^{8} \mathrm{C}_{\mathrm{M}}{ }^{1}\right)+\text { constant }
$$

Where, $\mathrm{C}_{\mathrm{HI}}{ }^{\mathrm{I}}$ and $\mathrm{C}_{\mathrm{M}}{ }^{\mathrm{I}}$ are concentrations of $\mathrm{H}^{+}$and $\mathrm{M}^{+}$in test- $\mathrm{I}$ solution, respectively, $\mu_{\mathrm{H}^{8}}$ and $\boldsymbol{\mu}_{\mathrm{H}}{ }^{8}$ are mobilities of $\mathrm{H}^{+}$and $\mathrm{M}^{+}$of the $\mathrm{pH}$-glasses, respectively. Therefore, the important factor for the response to $\mathrm{M}^{+}$ions of solution is the mobility of $\mathrm{M}^{+}$ions of 
TABLE 1.

"Major Mechanisms for pH-Glass Electrode Potential"

\{Year\} \{Proposed by\}. \{Origin of Potential\}.

\begin{tabular}{|c|c|c|}
\hline $\begin{array}{l}1906 \\
1931\end{array}$ & $\begin{array}{l}\text { Cremer } \\
\text { Dole }\end{array}$ & $\begin{array}{l}\text { Membrane or diffusion potential; } \\
\text { Glass membrane is permeable to } \mathrm{H}^{+}\end{array}$ \\
\hline 1909 & Haber & hase boundary or Donnan potential \\
\hline $\begin{array}{l}1923 \\
1937\end{array}$ & $\begin{array}{l}\text { Horovitz } \\
\text { Haugaad }\end{array}$ & $\begin{array}{l}\text { Ion adsorption or Ion exchange } \\
\text { between } \mathrm{Na}^{+} \text {and } \mathrm{H}^{+} \text {. }\end{array}$ \\
\hline 1941 & Haugaad & $\begin{array}{l}\text { Disproved } \mathrm{H}^{+-} \text {diffusion through } \\
\text { membrane by chemical analyeis }\end{array}$ \\
\hline $\begin{array}{l}1961 \\
1962\end{array}$ & $\begin{array}{l}\text { Schwabe \& Dahms } \\
\text { Hammond }\end{array}$ & Disproved $\mathrm{H}^{+-}$diffusion by tritium \\
\hline 1967 & Nicolsky & Ion exchange theory \\
\hline 1986 & Cheng & $\begin{array}{l}\text { Double-layer and double- capacitor } \\
\text { model } \\
\text { Disproved "Ion exchange theory" } \\
\qquad\left(\mathrm{H}^{+} \rightleftarrows \mathrm{Na}^{+}\right) \\
\text {Digsociation mechanism }\end{array}$ \\
\hline $1975 \cdot 96$ & Baucke & Dissociation mechanism \\
\hline $1997 \cdots$ & Abe & $\begin{array}{r}\mathrm{H}^{+} \text {-diffusion through membrane } \\
\text { (Presence of mobile } \mathrm{H}^{+} \text {in } \mathrm{pH} \text {-glass) }\end{array}$ \\
\hline
\end{tabular}

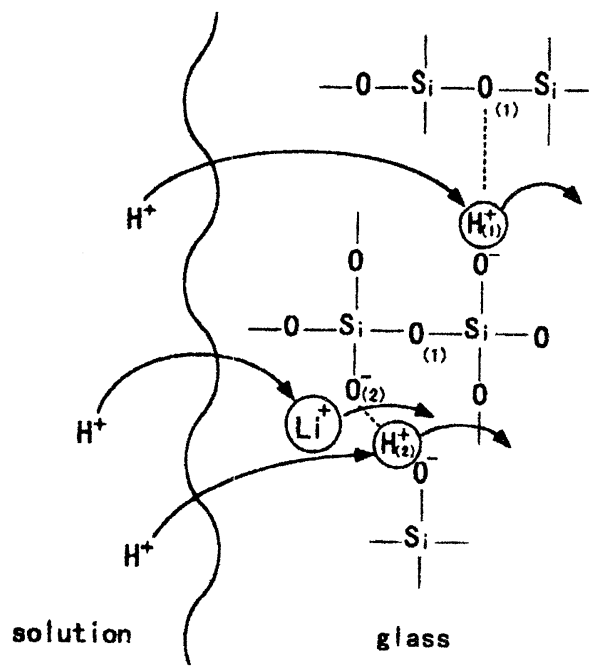

Fig. 6. Schematic representation of $\mathrm{H}^{*}$ - and $\mathrm{Li}^{+}$-ions in $\mathrm{pH}$-electrode glass structure. $\left(\mathrm{H}_{11}^{+}\right.$: hydrogen- bonding free, and immobile proton. $\mathrm{H}_{(2)}^{+}$: strongly hydrogen-bonded, and mobile proton. $O_{11}$ : bridging oxygen. $\mathrm{O}_{(2)}$ : non-bridging oxygen."

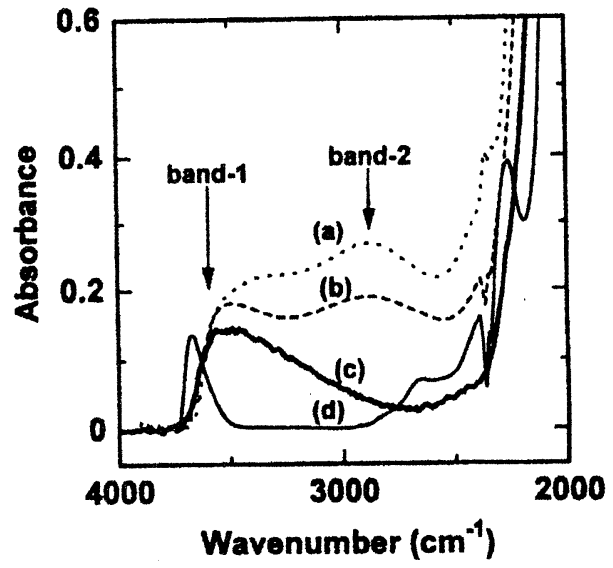

FIGURE 7. IR spectra (1 mm thick).

(a): pH-electrode glass.

(b): Window glass

(c): $20 \mathrm{Na} 2 \mathrm{O}-20 \mathrm{Al} 2 \mathrm{O} 3-60 \mathrm{SiO} 2$ glass

(d): $\mathrm{SiO} 2$ glass.

The Nernstian slope $(\mathrm{E} / \mathrm{pH}$, in $\mathrm{mV})$ is:

(a) -57, (b) $=43,(d)=4$ 
the glasses, but not their concentration. We assert; that the reason why the potential of glass electrodes originates in response to $\mathrm{pH}$ comes from the fact that high mobility protons are present in the glasses, and that the reason why $\mathrm{Na}_{2} \mathrm{O}-\mathrm{Al}_{2} \mathrm{O}_{3}-\mathrm{SiO}_{2}$ glasses shown in $\mathrm{Fi} .7$ exhibit less $\mathrm{pH}$-response and better pNa-response comes from the lack of mobile protons (band-2) of the glasses. When the mobile protons are decreased, the glasses become less pH-responsive. ${ }^{43}$ Even the silicon wafers when hydrogens are introduced by annealing in a $\mathrm{H}_{2}$ gas atmosphere, becomes $\mathrm{pH}$-responsive. ${ }^{47}$

\section{REFERENCES}

1. Y. Abe, H. Shimakawa, L.L. Hench, J.Non-Cryst. Solids, 51, 357 (1982).

2. Y. Abe, H. Hosono, Y. Ohta, L.L. Hench, Phys. Rev., B38, 10166 (1988).

3. H. Hosono, T. Kamae, Y. Abe, J.Am. Ceram. Soc., 72, 294 (1989).

4. H. Hosono, Y. Abe, J.Am. Ceram. Soc., 72, 44 (1989).

5. Y. Abe, H. Hosono, T. Kamae, K. Kawashima, Phosphorus, Sufur, and Silicon, 51/52, 113 (1990).

6. Y. Abe, D.E. Clark, J. Mater. Sci. Lett., 9, 244 (1990).

7. Y.Abe, H. Hosono, Y. Hikichi, L.L. Hench, J.Mater. Sci. Lett., 9, 1443 (1990).

8. M. Kotama, K. Nakanishi, H. Hosono, Y. Abe, L.L. Hench, L.Electrochem. Soc. $138,2928(1991)$.

9. H. Hosono, Y. Abe, K. Deguchi, J.Non-Cryst. Solids, 142, 103 (1992).

10. Y. Abe, H. Hosono, W-H. Lee, T. Kasuga, Phys. Rev., B48, 15621 (1993).

11. Y. Abe, H. Hosono, O. Akita, L.L. Hench, J.Electrochem. Soc., 141, L64 (1994).

12. (a) Y. Abe, Proc. $17^{\text {th }}$ Intern. Cong. Glass, 1,105 (1995).

(b) Y. Abe, G. Li, K. Kawashima, Japan Patent Appl. No. H6-257531 (1994).

13. Y. Abe, G. Li, M. Nogami, T. Kasuga, Proc. $17^{\text {th }}$ Intern. Cong Glass, 2,262 (1995).

14. G. Li, M. Nogami, Y. Abe, Solid State Ionics, 83, 209 (1996).

15. Y. Abe, G. Li, M. Nogami, T. Kasuga, L.L. Hench, J.Electrochem. Soc. 143, 144 (1996).

16. K. Kawamura, H. Hosono, H. Kawazoe, N. Matsunami, Y. Abe, I. Ceram. Soc. Japn, 104, 688 (1996).

17. H. Hosono, K. Kawamura, H. Kawazoe, N. Matsunami, Y. Abe, J. Appl. Phys., 81, 1296 (1997).

18. M. Nogami, Y. Abe, Phys. Rev., B55, 12108 (1997).

19. K. Makita, M. Nogami, Y. Abe, J. Mater. Sci.Lett., 16, 550 (1997).

20. M. Nogami, R. Nagao, K. Makita, Y. Abe, Appl. Phys. Lett., 77, 1 (1997).

21. M. Nogami, K. Miyamura, Y. Abe, J. Electrochem. Soc., 144, 2175 (1997);

22. K.Makita, M. Nogami, Y. Abe, J Ceram. Soc. Jpn., 105, 595 (1997).

23. K. Makita, M. Nogami, Y. Abe, L. Ceram. Soc. Jpn., 105, 647 (1997),

24. K. Makita, M. Nogami, Y. Abe, J.Mater. Sci._ett., 16, 550 (1997).

25. K. Makita, M. Nogami, Y. Abe, J. Ceram. Soc. Jpn, 196, 398 (1998).

26. C. Wang, M. Nogami, Y. Abe, J. Sol-Gel Sci. Tech., 14,273 (1999)

27. C. Wang, Y. Abe, T. Kasuga, M. Nogami, J. Ceram. Soc.Jpn., 107, 1037 (1999).

28. Y. Abe, Proc. $3^{\text {rd } I n t e r n . ~ S y m p . ~ I n o r g . ~ P h o s ~ M a t e r ., ~(P h o s . ~ R e s . ~ B u l l . ~ 10, ~} 49$ 
(1999).).

29. For example: (a) F.M.Ernsberger, J Non-Cryst Solids, 87, 408 (1986); (b) I. Am. Ceram. Soc., 66, 747 (1983); (c) Phys. Chem. Glasses, 21, 146 (1980).

30. H. Scholze, Glastech. Ber. 32, 81(1959): "Glass", (Springer-Verlag, 1991). p.241.

31. G.C. Milnes, J.O. Isard, Phys.Chem.Glasses, 3, 157 (1962).

32. B.M. Cohen, D.R. Uhlmann, J. Non-Cryst. Solids, 12,177 (1973)

33. P.J.Melling, J.F. Duncan, Phys. Chem. Glasses, 20, 102 (1979).

34. B. Dutta, R.H. Magruder, R.A. Weeks, D.L. Kinser, J. Am. Ceram. Soc., 71, 1100 (1988).

35. K. Hughes, J.O. Isard, G.C. Milnes, Phys. Chem. Glasses, 9,43 (1968).

36. J.A. Topping, M.K. Murthy, L.Am.Ceram.Soc. 57,281 (1974).

37. Y. Abe, M. Hayashi, T. Iwamoto, Japan Patent Application No.2001-316962

38. K. Honda, A. Fujishima, Nature, 238, 37 (1972).

39. Z. Zou, J. Ye, K. Sayama, H. Arakawa, Nature, 414, 625(2001)

40. R. Asai, T. Morikawa. T. Ohwaki, K. Aoki, Y. Taga, Science, 293, 269(2001).

41. Y.Abe, M. Maeda, Phys. Chem. Glaases, 37, 176 (1996).

42. Y. Abe, M. Maeda, ibid., 38, 338 (1997).

43. Y. Abe, M. Nogami, M. Maeda, J.Non-Cryst. Solids, 209, 204 (1997).

44. Y. Abe, M. Maeda, J. Ceram. Soc. Jpn., 105, 628 (1997).

45. Y. Abe, M. Maeda, N. Hayakawa, H. Umehara, M. Nogami, Mater. Res. Bull., 32, 1535 (1997).

46. Y. Abe, M. Maeda, H. Hayakawa, J.Mater. Sci., 32, 4183 (1997).

47. Y. Abe, M. Nogami, T. Matsubara, K. Kashima, Solid State Comm., 106, 321 (1998).

48. Y. Abe, M. Nogami, Proc. $18^{\text {th }}$ Intern. Cong. Glass (San Francisco, 1998)

49. Y. Abe, M. Maeda, J.Electrochem. Soc, 147, 787 (2000).

50. M. Cremer, Z. Biol., 47, 562 (1906).

51. M. Dole, J.Am. Chem. Soc., 53, 4260-4280, (1931).

52. G. Haugaad, J.Phys. Chem., $45,148-157,(1941)$.

53. K. Scwabe, H. Dahms, Q. Nguyen, G. Hoffmann, Z. Electrochem., 66, 304, (1962)

54. P.R. Hammond, Chem. \& Ind., Feb.311 (1962).

55. For example: (a) R.A. Day, Jr. \& A.L. Underwood, "Quantitative Analysis" (Prestine-Hall, New Jersey, 1989), $4^{\text {th }}$ ed., pp.308.

(b) J.S. Fritz \& G.H. Schenk, "Quantitative Analytical Chemistry" (Allyn and Bacon, 1974), $3^{\text {rd }}$ ed., pp.338.

(c) H. Bach, F.G.K. Baucke, D. Krause, edited. "Electrochemistry of Glasses and Glass Melts, Including Glass Electrodes" (Springer-Verlag, Berlin, 2001).

56. F.G.K. Baucke, H. Gach, J.Am. Ceram. Soc., 65, 534 (1982). 